\title{
PERIODONTAL DISEASES IN DOGS (ETIOLOGY, CLINICAL SIGNS, DIAGNOSIS)
}

\author{
M. A. KULIDA, Candidate of Veterinary Sciences, Associate Professor, \\ Department of Surgery and Pathophysiology \\ named after Academician I. O. Povazhenko \\ https://orcid.org/0000-0001-8937-1972
}

National University of Life and Environmental Sciences of Ukraine, Kyiv, Ukraine E-mail:mkulida@ukr.net

S. M. TKACHENKO, Candidate of Veterinary Sciences, Associate Professor, Department of Surgery and Pathophysiology named after Academician I. O. Povazhenko https://orcid.org/0000-0002-2775-1387

National University of Life and Environmental Sciences of Ukraine, Kyiv, Ukraine E-mail: tkachenko_sm@nubip.edu.ua

\begin{abstract}
Recently, the number of non-communicable pathologies in dogs is increasing and a large part of them are caused by diseases of the oral cavity area. $A$ significant number of them are dental problems. One of them is periodontitis.

More often periodontitis occurs as a result of tooth fractures and the development of caries, which are complicated by necrotic pulpitis. The main forms of periodontitis in dogs: fibrous, granulomatous, granulating, and suppurative.

The work describes clinical manifestations of periodontal pathology and interprets the radiological images taken for final diagnosis of oral cavity pathology.

Fibrous periodontitis was found to be asymptomatic and characterized by insignificant equitable expansion of the periodontal slit in the apex area. Granulating periodontitis is characterized by hyperemia and swelling of the mucous membrane of the gums in the area of tooth root projection and uneven jaw bone destruction with deformation of the periodontal slit. Granulomatous periodontitis is asymptomatic and is characterized by the development of a rounded defect of the jaw bone, which is associated with periodontitis and is radiologically detected. A fistula in the infraorbital region (fourth upper premolar) is observed quite often. In cases of suppurative periodontitis in dogs, toothache, hyperemia and swelling of the gums, fistula, destruction and melting of the periodontal ligament were noted.

Odontogenic abscesses can be considered not only as an independent nosologic unit but also as a kind of suppurative periodontitis. Granulomas of periodontal tissue are a part of chronic periodontitis including its similar etiology, pathogenesis, symptoms, and localization.
\end{abstract}

Keywords: fistulas, caries, tooth fractures, deformation, periodontal slit 


\section{Introduction}

Recently, the number of non-communicable pathologies in dogs has been increasing, the majority of which are caused by diseases of the oral cavity. A significant number of them are dental problems.

One of them is periodontitis, which is widespread in $15-23 \%$ of cases (Borisevich, 1997; Lovegrove, 2004) among dental diseases in dogs, and according to Petrenko (1998), this pathology constitutes $7 \%$ of all dental diseases in veterinary medicine.

The main etiological factors of periodontal diseases are dental trauma followed by penetration of infection into the tissues of the oral cavity through the tooth or by the hematogenous route. But the presence of dental calculus can also be a source of infection.

Regardless of the causes of occurrence, periodontal pathology has clinical signs that are manifested by symptoms of inflammation, which must be differentiated from other pathologies in the oral cavity. In each particular case, it is necessary to combine different methods of diagnostics to clarify the diagnosis, which is important both for practicing veterinarians and scientists.

\section{Analysis of recent researches and publications}

The root of the tooth is connected to the bone tissue of the jaw by the connective tissue sheath, which is called periodontium (Small, 1967). The periodontium is a connective tissue located between the root and the dental alveolus. Physiologically, the structure of the periodontium corresponds to the structure of the periosteum (Nimand \& Suter, 1998).

The important function of the periodontium in animals is the retention and cushioning of the teeth because the teeth of predators are subjected to different loads during the retention of prey or the gnawing of bones.

Periodontitis is the inflammatory process in the structures of the periodontal tissues - periosteal inflammation in the tooth root area, i.e. inflammation of the periodontium (Lukyanovsky et al., 1988; Frolov, 2003).

Periodontitis apart from inflammation of the periodontium is also characterized by inflammation of the periosteum, which can be marginal, apical, or diffuse (Belov et al., 1990; Pinto et al., 2020). Periodontal disease is divided into acute and chronic, and into aseptic and purulent (Nises et al., 2018).

Periodontal diseases also include odontogenic abscesses, which according to Frolov (2003) have a prevalence of up to $10 \%$ of clinical cases. They occur as a result of the penetration of microorganisms into the tissues of the jaw around the tooth by exogenous or endogenous route (Pavlica et al., 2008). This results in the melting of some tissues with clearly demarcated purulent inflammation and necrosis (Simpson et al., 2003; Frolov et al., 2003, 2006; Wallis et al., 2015).

Granulomas of periodontal tissue occur in dogs not more often than abscesses and are characterized by peri-apical proliferative inflammatory processes, which lead to local bone resorption (Small, 1967; DeBowes et al., 1996). In this case, there is a spread of infection, colonization by secondary microflora, accumulation of decay products, and alveolar pyorrhea (Enlund et al., 2020). Pus may come out of the formed fistula into the oral cavity, alveolus of the tooth but its release is often visible with the penetration of the skin under the eye or in the nose (Simpson et al., 2003; Garanayak et al., 2019). 
According to Loesche (1985), periodontal disease is a combined term given to the different inflammatory conditions of the tissue, which support and bond the teeth to the jaw bone. The inflammatory reaction occurs to bacterial products and/or bacteria that enter the tissues from the dental plaque.

Dental plaque is a complex microbial community containing about 190 different taxons that exist on dental surfaces (Harvey, 1998). Until recently, there were few consensus pathogens, and trying to distinguish pathogenic from nonpathogenic was a difficult task for dental researchers for a variety of reasons (Joanne et al., 2004). Periodontal disease is widespread and often has a very severe course in dogs. This is caused by the accumulation of bacterial plaque, especially gram-negative anaerobic rods. Tissue rupture results from autodegradation caused by an ongoing inflammatory reaction. Small dogs are, particularly, at risk. Prophylaxis by slowing the accumulation of plaque is a key concept (Harvey, 1998).

The results of the research show that there is a relationship between the predicted "burden of periodontal disease", which is caused by periodontal diseases associated with bacterial plaque, and the level of internal pathology in the examined group of animals, bearing in mind that periodontitis can contribute to the development of systemic pathology in dogs (Pavlica et al., 2008).

Thus, the analysis of literary sources shows that the issues of etiology, treatment, symptoms, and diagnostics of canine periodontal diseases are insufficiently covered in the Ukrainian veterinary community. It should also be noted the contradictions in the classification of these pathologies.

Purpose. To investigate etiology, symptoms, and to conduct radiological examination in dogs with different forms of periodontitis.

\section{Materials and methods of research}

The work was carried out on the basis of the veterinary and surgical center "Chance", located in Kyiv on Volzka Street. Among the animals admitted to the reception according to the results of the clinical examination, 20 dogs with the final diagnosis "periodontitis" were selected.

Animals for study were selected according to the results of the clinical examination in dogs by the generally accepted methods taking into account anamnestic data. Special attention was paid to the examination of the oral cavity, the condition of the mucous membrane of the oral cavity was determined: gums, hard and soft palate. The position, shape, color, the number of teeth and their mobility were determined. Probing of carious cavities on toothless areas was performed, alveoli were examined.

Radiography of organs of the maxillofacial system is one of the most widely used methods of examination. Radiography gives valuable information about the condition of hard tissue of the crown and root, size and features of the tooth cavity, root canals, width and character of the periodontal slit, condition of the compact plate of an alveolar wall and spongy part of the alveolar process. That is why to clarify the diagnosis we carried out a radiological examination of the oral cavity in dogs using extraoral imaging in rigid cassettes and intraoral - in small cassettes. Apart from intraoral (focused) imaging, the pantomography method was used, which allows obtaining panoramic radiographs of dental rows and jaws. Using extraoral radiography (in different settings), we examined areas of the upper and lower jaws, the temporomandibular joint, and the bones of the facial part of the skull. 


\section{Results of the research and their discussion}

All cases of periodontitis manifested themselves by the presence of caries or old tooth fractures with pulp exposure. These pathologies were accompanied by necrotizing pulpitis. The manifestation of the disease in the animals was not dependent on the breed or gender characteristics of the dogs. The age of the diseased animals varied from 5 to 12 years. Localization and causes of periodontitis in the studied dogs are given in Table 1.

Our tests showed that the causes of periodontitis in dogs were tooth fractures in $75 \%$ of the animals and dental caries in only $25 \%$ of cases.

All the animals that had tooth fractures showed tooth deformation as a result of complete or partial loss of the crown, presence of the broken surface, the area of pulp exposure, and in case of caries, the destruction of the crown and the softening of the walls and bottom of its cavity, and penetration into the pulp chamber is marked.

During the examination with periodontal instruments, the pulp was removed in pieces, grayish-black in color, without bleeding, indicating its necrosis.

Animals with oral cavity pathology underwent radiological examination.

$\mathrm{X}$-ray images clearly showed violations of the anatomical shape of the tooth and pathological processes in the peri- odontium, which varied depending on the form of the disease.After conducting all the necessary examinatons, the following forms of periodontitis were identified in the studied dogs: fibrinous, granulating, granulomatous, and purulent.

Fibrinous periodontitis was observed in 7 cases ( 5 fourth premolars and two canines). At the same time pain was absent, with their mobility and change of gingival tissues. On X-ray images - slight uniform expansion of the periodontal slit around the apex of the root in the form of a strip in the area of the apex, which was limited by the contours of the tooth and the uneven line of the compact plate of the jaw bone (Fig. 1).

Granulating periodontitis was observed in two cases (fourth premolars with fistulas). During the examination of this group, there was no tooth pain, the teeth were undisturbed, there was a slight hyperemia and swelling of the gingival mucosa at the site of the tooth root projection. On the X-ray images, we observed uneven enlargement and deformation of the periodontal slit near the root apex with jaw bone rupture, osteolysis manifested as a darkened area near the apex with blurred edges. A characteristic feature was an uneven toothed line of a compact lamina of the tooth sockets with sites of wedge-shaped entrance into it of the periodontium (Fig. 2). Granulomatous periodontitis

1. Localization and causes of periodontitis in $\operatorname{dogs}(M \pm m, n=20)$

\begin{tabular}{|l|c|c|c|c|}
\hline $\begin{array}{c}\text { The cause of } \\
\text { periodontitis }\end{array}$ & Jaw & Tooth type & $\begin{array}{c}\text { Number of } \\
\text { occurrences }\end{array}$ & $\%$ \\
\hline Caries & Upper & 1st molar & 4 & 20 \\
\hline & & 4th premolar & 1 & 5 \\
\hline Tooth fractures & Upper & Canines & 2 & 10 \\
\hline & & 4th premolar & 9 & 45 \\
\hline & Lower & Canines & 4 & 20 \\
\hline
\end{tabular}




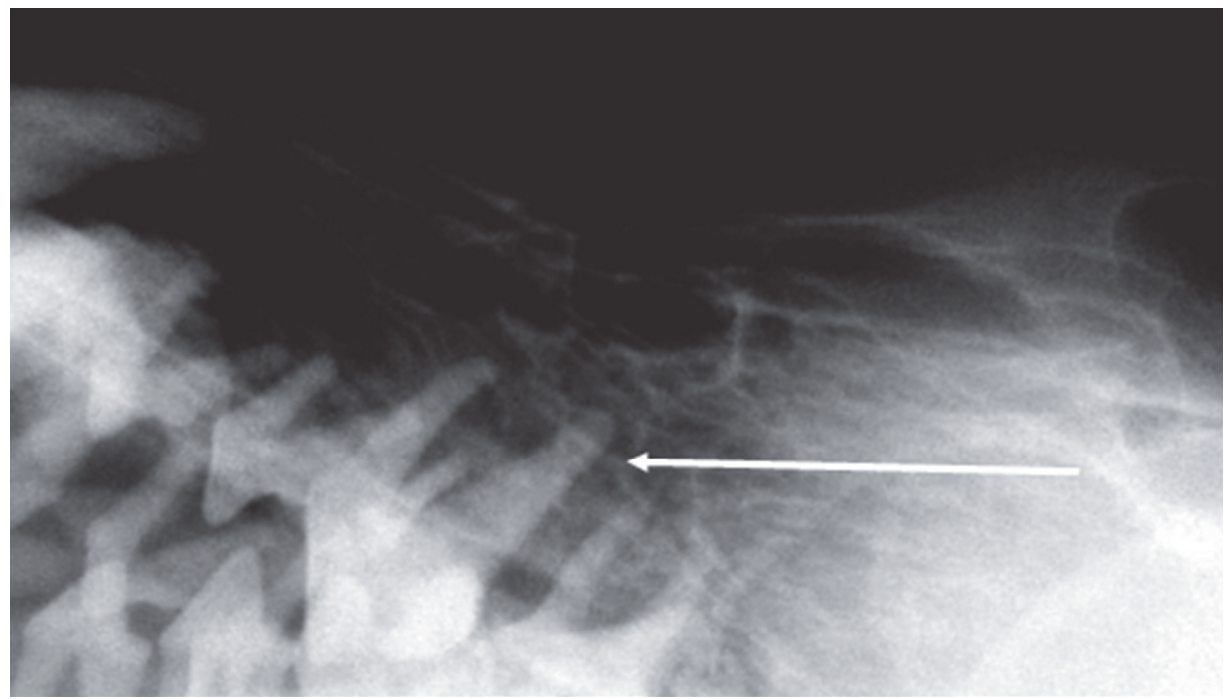

Fig. 1. Fibrous periodontitis of the fourth upper premolar

was observed in 8 animals (four canines and four fourth premolars). In this group, oral cavity examination did not show tooth pain, and there were no changes in the tooth mobility and the gingival tissues. Three dogs with premolar fractures were found to have fistulas in the periorbital region, with swelling and pain in the eyelids (the fistulas disappeared after tooth extraction).

$\mathrm{X}$-rays revealed granulomas attached to the tooth root in the bone (in the form of a sac), which appeared as intense rounded darkening in the jaw, connected with the tooth root, clearly separated from the surrounding tissues (Fig. 3).

Fig. 2. Granulating periodontitis of the fourth upper premolar 


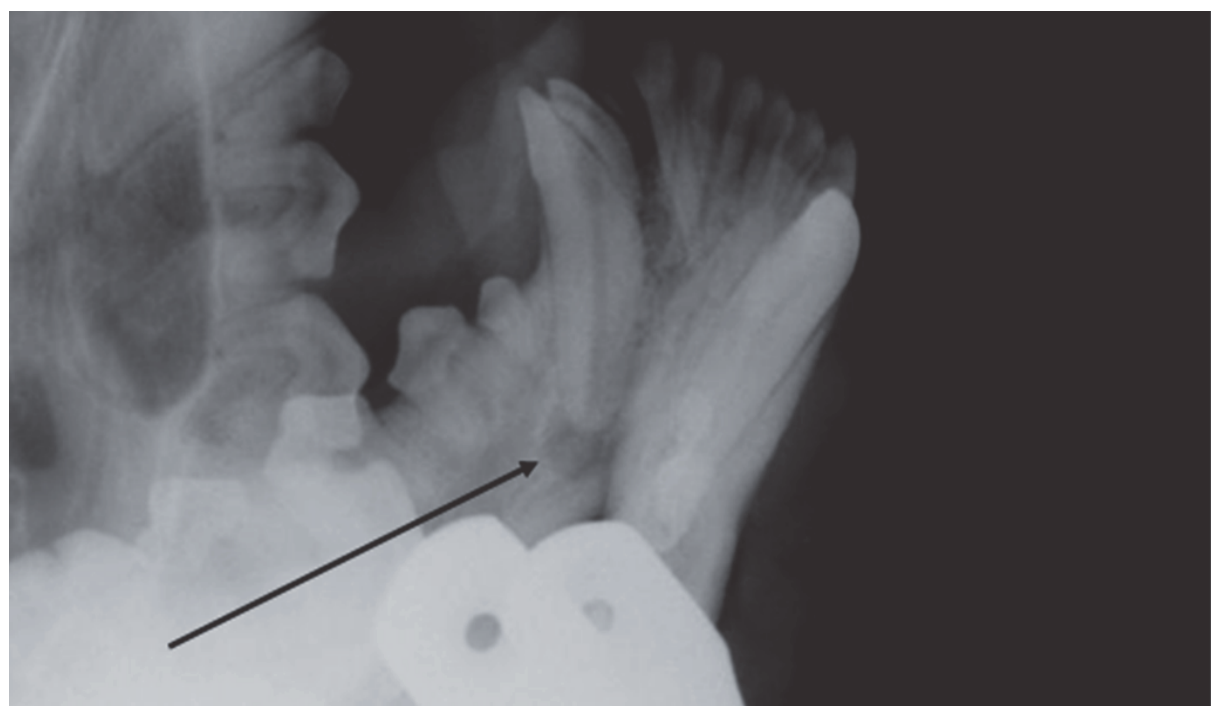

Fig. 3. Granulomatous periodontitis of the lower canine

The digital image clearly shows a thin opening of the fistula, which stretched cranially along the maxillary bone. In acute suppurative periodontitis, local and general manifestations of pain are pronounced. Pain sensations increase. As a result of the purulent melt- ing of the ligamentous apparatus, the tooth becomes mobile.

Acute suppurative periodontitis is sometimes accompanied by the appearance of collateral edema in the soft tissues of the head and hyperemia of the gums in the area of the diseased tooth forming an abscess.

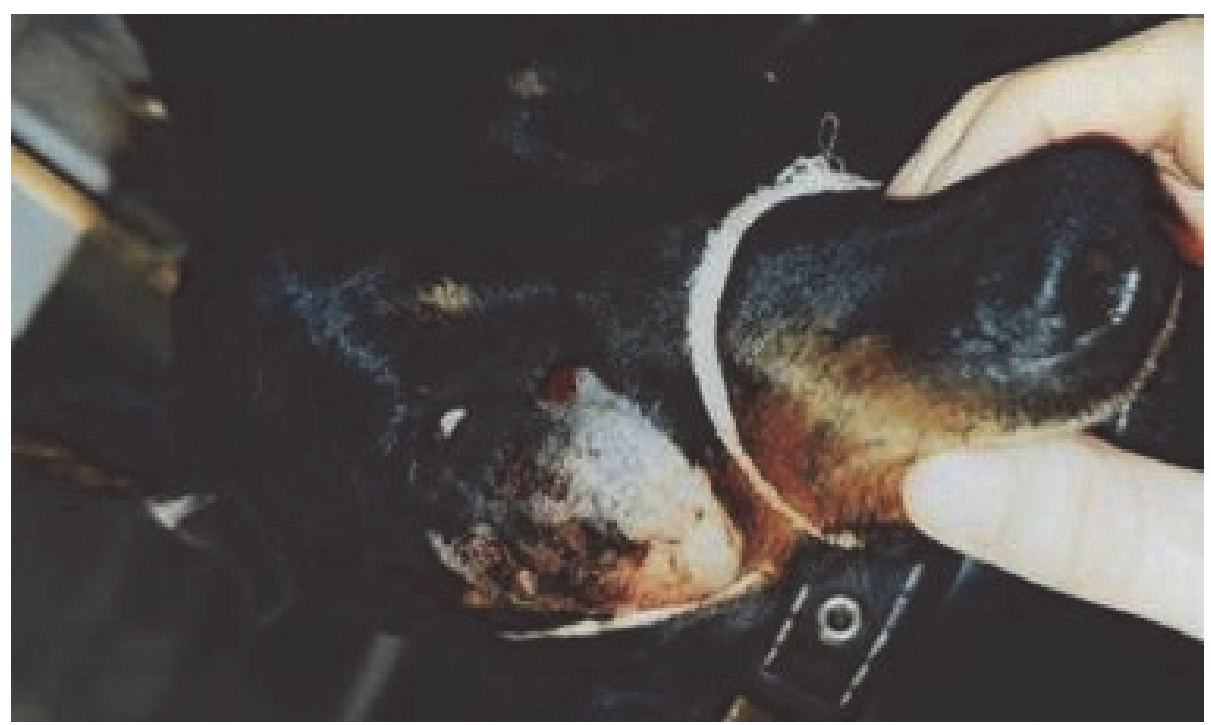

Fig. 4. Turgidity in the infraorbital region with swelling of eyelids due to suppurative periodontitis of the fourth upper premolar in a dog 
Suppurative periodontitis was observed in three animals (in two of them - the first premolar, in one - the fourth premolar of the upper jaw) as a result of caries. Toothache, hyperemia, and swelling of gums were noted. When the upper premolars are affected - fistula in the infraorbital region with swelling of eyelids and abscesses (Fig. 4).

In chronic periodontitis, we noted changes in the position of teeth, increased degree of their mobility, the appearance of interdental fissures. With exacerbation of periodontitis, the bleeding of the gums was observed. In advanced cases, the external output of purulent exudate with disruption of the integrity of the skin covering in the area between the lower eyelid and the upper jaw (formation of fistulas) was observed.

When caries of the fourth premolar, there was strong mobility of the tooth, the gums were detached from its neck and the release of purulent exudate was seen, and when caries of the canines, the gums were detached from the neck of the tooth (Fig. 5).
The previous diagnosis was made on the basis of oral cavity examination. Attention was paid to the presence of swelling of the salivary glands, lymph nodes, dental calculus, and gingivitis. Residual conclusions were made after oral cavity examination under general anesthesia (the degree of dental calculus formation, the depth of periodontal pocket were determined).

\section{Conclusions and future perspectives}

The main cause of periodontitis in dogs is tooth fractures and caries, which are complicated by necrotic pulpitis.

Fibrous periodontitis has an asymptomatic course and is characterized by a slight equitable expansion of the periodontal slit in the apex area.

Granulating periodontitis is characterized by hyperemia and swelling of the gingival mucosa at the site of the tooth root projection and uneven destruction of the jaw bone with deformation of the periodontal slit.

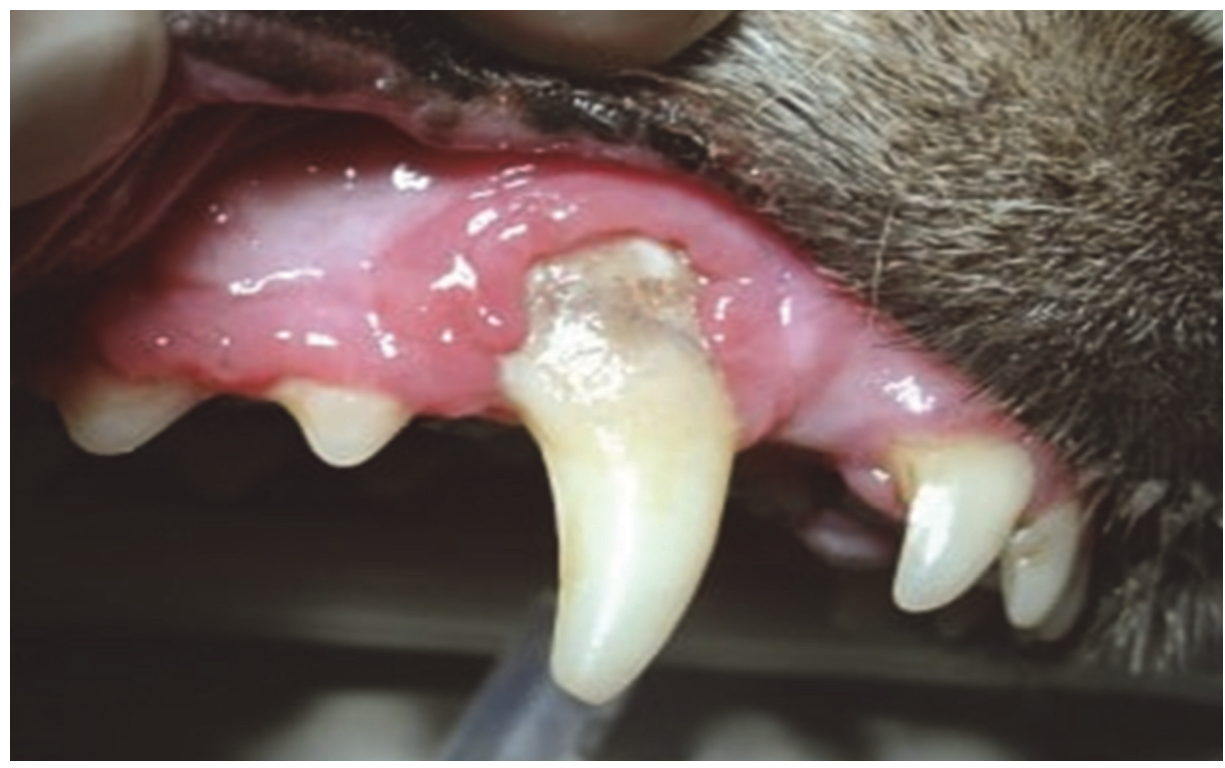

Fig. 5. Gum detachment from the neck of the tooth 
Granulomatous periodontitis has an asymptomatic course and is characterized by the development of a rounded defect of the jaw bone associated with periodontitis that is radiologically detected. Fistulas in the infraorbital region (fourth upper premolar) may sometimes be observed.In case of suppurative periodontitis in dogs, a toothache, hyperemia and swelling of the gums, fistulas, destruction and melting of the periodontal ligament are noted.

Odontogenic abscesses can be considered not only as an independent nosologic unit but also as a kind of suppurative periodontitis. Granulomas of periodontal tissue are a form of chronic periodontitis, taking into account their similar etiology, pathogenesis, symptoms, and localization.

\section{References}

Belov, A. D., Danilov, E. P., \& Dukur, I. I. (1990). Bolezny sobak. Spravochnyk [Diseases of dogs. Directory]. Moscow: Agropromizdat.

Borisevich, V. B., \& Borisevich, B. V. (1997). Bolezny $v$ oblasty golovy [Diseases in the head region]. Kyiv.

DeBowes, L. J., Mosier, D., Logan, E., Harvey, C. E., Lowry, S., \& Richardson, D. C. (1996). Association of periodontal disease and histologic lesions in multiple organs from 45 dogs. Journal of Veterinary Dentistry, 13(2), 57-60.

Enlund, K. B., Brunius, C., Hanson, J., Hagman, R., Höglund, O. V., Gustås, P., \& Pettersson, A. (2020). Dog owners' perspectives on canine dental health-a questionnaire study in Sweden. Frontiers in Veterinary Science, 7, 298. doi: 10.3389/fvets.2020.00298.

Enlund, K. B., Brunius, C., Hanson, J., Hagman, R., Höglund, O. V., Gustås, P., \& Pettersson, A. (2020). Dental home care in dogs-a questionnaire study among Swedish dog owners, veterinarians and veterinary nurses. BMC veterinary research, 16(1), 1-13. doi: 10.1186/s12917-020-02281-y.
Frolov, V. V. (2003). Bolezni zubov i polosty rta u sobak [Diseases of the teeth and oral cavity in dogs]. Moscow: Aquarium book.

Frolov, V. V., Volkov, A. A., Aninkov, V. V., \& Beidyk, O. V. (2006). Stomatolohyia sobak [Dentistry of dogs]. Moscow: Aquarium-print.

Garanayak, N., Das, M., Patra, R. C., Biswal, S., \& Panda, S. K. (2019). Effect of age on dental plaque deposition and its control by ultrasonic scaling, dental hygiene chew, and chlorhexidine $(0.2 \% \mathrm{w} / \mathrm{v})$ in dogs. Veterinary world, 12(11), 1872-1876. doi: 10.14202/ vetworld.2019.1872-1876.

Harvey, C. E. (1998). Periodontal disease in dogs: etiopathogenesis, prevalence, and significance. Veterinary Clinics of North America: Small Animal Practice, 28(5), 1111-1128. doi: 10.1016/s0195-5616(98)50105-2.

Lee, S., Lee, K., Kim, H., An, J., Han, J., Lee, T., ... \& Cho, Y. (2020). Comparison of dental radiography and computed tomography: measurement of dentoalveolar structures in healthy, small-sized dogs and cats. Journal of Veterinary Science, 21(5). doi: 10.4142/jvs.2020.21.e75.

Loesche, W. J. (1985). The therapeutic use of antimicrobial agents in patients with periodontal disease. Scand J Infect Dis Suppl, 46, 106-14.

Lovegrove, J. M. (2004). Dental plaque revisited: bacteria associated with periodontal disease. Journal of the New Zealand Society of Periodontology, (87), 7-21.

Lukianovskyi, V. A., Filatov, Yu. I., \& Kopenkyn, E. P. (1988). Bolezny sobak [Diseases of dogs]. Moscow: Rosagropromizdat.

Nimand, H. G., \& Suter, P. F. (1998). Zabolevanyia zubov [Diseases of the teeth]. Moscow: Aquarium.

Nises, J., Rosander, A., Pettersson, A., \& Backhans, A. (2018). The occurrence of Treponema spp. in gingival plaque from dogs with varying degree of periodontal disease. PLoS One, 13(8), 20182088. doi: 10.1371/journal.pone.0201888.

Pavlica, Z., Petelin, M., Juntes, P., Eržen, D., Crossley, D. A., \& Skalerič, U. (2008). Peri- 
odontal disease burden and pathological changes in organs of dogs. Journal of veterinary dentistry, 25(2), 97-105.

Petrenko, O. F. (1998). Kharakter urazhennia zubiv u sobak ta kishok [The nature of lesions of teeth in dogs and cats]. Kyiv: NAU. Pinto, C. F., Lehr, W. O., Pignone, V. N., Chain, C. P., \& Trevizan, L. (2020). Evaluation of teeth injuries in Beagle dogs caused by autoclaved beef bones used as a chewing item to remove dental calculus. PLoS One, 15(2), 2281-2286. doi: 10.1371/journal. pone.0228146.
Simpson, D. U., \& Els, R. U. (2003). Zabolevanyia polosty rta y glotky [Diseases of the mouth and throat]. Moscow: Aquarium book.

Small, E. (1967). Diseases of the Mouth and Esophagus. Journal of the American veterinary medical association, 151(12), 1714-1718.

Wallis, C., Marshall, M., Colyer, A., O'Flynn, C., Deusch, O., \& Harris, S. (2015). A longitudinal assessment of changes in bacterial community composition associated with the development of periodontal disease in dogs. Veterinary microbiology, 181(3-4), 271-282. doi: 10.1016/j.vetmic.2015.09.003.

\section{М. А. КУЛіда, С. М. ТКवчеНКО (2021). ХВОРОБИ ПЕРІОДОНТА У СОБАК} (ЕТІОЛОГІЯ, КЛІНІЧНІ ОЗНАКИ, ДІАГНОСТИКА). Ukrainian Journal of Veterinary Sciences, 12(1): 23-31, https://doi.org/10.31548/ujvs2021.01.003

Анотація. Останнім часом збільшується кількість незаразних патологій собак, серед яких доволі великий відсоток припадає на хвороби в діляниі ротової порожнини. Значну кількість серед них займають стоматологічні проблеми. Однією з них є періодонтит.

Частіше періодонтити виникають унаслідок переломів зубів та розвитку карієсу, які ускладнюються некротичним пульпітом. Основні форми періодонтитів у собак: фіброзний, гранулематозний, гранулюючий та гнійний.

У роботі описано клінічні прояви патологій періодонта та проведено інтерпретацію рентгенологічних знімків, які зробили для остаточної діагностики патологій ротової порожнини.

Встановлено, що фіброзний періодонтит має безсимптомний перебіг і характеризується незначним рівномірним розширенням періодонтальної щілини в ділянці апекса. $3 а$ гранулюючого періодонтиту спостерігали гіперемію та набряк слизової оболонки ясен у місці проєкції кореня зуба та нерівномірне руйнування щелепної кістки з деформацією періодонтальної щілини. Гранулематозний періодонтит має безсимптомний перебіг і характеризується розвитком округлого дефекту щелепної кістки, який пов'язаний із періодонтитом і виявляється рентгенологічно. Досить часто спостерігали утворення нориці в підочній ділянці (четвертий верхній премоляр). Під час гнійного періодонтиту в собак відзначали болючість зубів, гіперемію і набряк ясен, нориці, руйнування та розплавлення періодонтальної зв'язки.

Зважаючи на це, одонтогенні абсцеси можуть розглядатися не тільки, як самостійна нозологічна одиниия, а й як різновид гнійного періодонтиту, відповідно гранульоми періодонтальної тканини - як форма хронічного періодонтиту, що, на нашу думку, є більш обгрунтованим, з огляду на їхню подібну етіологію, патогенез, симптоми та локалізацію.

Ключові слова: нориці, карієс, переломи зубів, дерормація, періодонтальна щілина 